\title{
Public Private Partnership: Insights from the Egyptian Experience
}

\author{
Heba Samir \\ Assistant Professor of Business Administration at the Faculty of Management Sciences, \\ October University for Modern Sciences and Arts (MSA), Egypt
}

Aya Maher

Associate Professor of Human Resources Management (Adjunct Faculty),

School of Business \& School of Sciences \& Engineering, The American University in Cairo (AUC), Egypt

Received: July 12, 2018 Accepted: July 30, 2018 Online published: July 31, 2018

doi:10.5296/ijhrs.v8i3.13450 URL: https://doi.org/10.5296/ijhrs.v8i3.13450

\begin{abstract}
Partnership between private and public organizations has become very vital for policy implementation. PPP contracts have been successful for the recent years in many countries such as United Kingdom, Germany, Netherlands, South Africa, and The United States. Egypt is considered to be one of the MENA region leaders in the PPP field. PPPs are considered to be on the top of the Egyptian economic reform agenda so as to increase the private sector involvement in public services through leveraging private sector spending against public spending. The objective of this theoretical paper is to analyze the role of public private partnership in Egypt with regards to developing meaningful cooperation between the governments and businesses in a way that enables effective provision of cost efficient quality public goods, services and facilities. The significance of the study lies in the fact that PPP has become a crucial need for the government of Egypt for rendering an efficient public services and projects amidst all the challenges for developing the country after the $25^{\text {th }}$ of January Revolution.
\end{abstract}

Keywords: public private partnership (PPP), Egypt PPP, leveraging public sector, cooperation government \& private

\section{Defining Public Private Partnership (PPP)}

Public private partnership (PPP) can be defined as a government and private company 
venture through which the private party collaborates with the government assuming substantial financial, operational, and technical risk for the sake of undertaking a project for efficient and effective delivered public service.

PPP has two basic drivers, the first one is considered to be a technical one which is the exploitation of the private sector's expertise and technical capabilities in the delivery of a more developed public service. The second one is a financial driver that allows the public sector to be able to make a capital investment without incurring any borrowings (Barlow et al., 2013).

\subsection{PPP Methods}

Public Private Partnership contracts take several forms and can be applied through a variety of methods that vary according to the degree of involvement of either the public or the private sector. The different PPP methods will be discussed starting with the method with the highest involvement of the public sector and lowest involvement of the private sector and ending with the opposite (World Development Report, 1994):

1- Service Contracts: a short term (6months up to 2 years) contractual obligation between a public sector entity and one or more private sector entity/entities, based upon this contract the private sector entity is responsible for performing certain tasks of setups and/or maintenances in return for pre-determined fees (Zaki, 1999).

2- Management contracts: a contract between a public and private entities where the right of management of a certain organization or project is being delegated to the private entity but the property right still belong to the public entity. The private entity then is receiving fees for operating the organization and those fees can be linked to the profitability of the organization being managed. The length of this type of contracts ranges from 3 to 5 years. The public sector entity is responsible for any risk or loss resulting from the organization's operations (El Dessouky, 1995).

3- Leasing contracts: a contract through which the public sector entity gives the right to a private sector entity to utilize an asset and to keep the profits for a period of time between 6 to 10 years in return for paying rent. The private sector entity is responsible for the commercial risks which makes it motivated to reduce the expenditures and to maintain the value of the asset, while the public entity is still responsible for the fixed investments and servicing debts (El Sadek, 1995).

4- Concession contracts: when the public entity grants a concession contract to a private entity, then all the rights of operating and developing the organization or the asset are being transferred to the private entity (the beneficiary). The private entity then is responsible for all the capital expenditures, debts servicing and investments. The public entity takes back the organization or the asset by the end of the concession contract which lasts for 15 to 30 years depending on the investment life cycle (Zaki, 1999).

5- Build, Operate, Transfer (BOT): Under a build-operate-transfer (BOT) contract, a public sector entity grants a concession to a private company to finance, build and operate a project. 
This private company is responsible for operating the project for a period of time that can extend up to 20 or 30 years with the goal of recouping its investment, then transfers control of the project to the government. BOT projects are normally large-scale infrastructure projects that would otherwise be financed, built and operated solely by the government. BOT used to be known as concession contracts and they were very common late 1800s and early 1900s in France and in other several countries. France depended on such contracts in conducting railway projects, electricity stations, and drinking water projects. This type of contracts was firstly applied in Egypt during 1940s for supplying Heliopolis district with electricity, water, and tramway stations.

6- Build, Own, Operate, Transfer (BOOT): Under the BOOT system the public-sector entity contracts with a private developer - typically a large corporation or consortium of businesses with specific expertise - to design and implement a large project. The public-sector entity may provide limited funding or some other benefit (such as tax exempt status) but the private entity is expected then to bear the risks associated with planning, constructing, operating and maintaining the project for a specified time period. During that time, the private entity charges customers who use the infrastructure that's been built to realize a profit. At the end of the specified period, the private entity transfers ownership to the funding organization, either freely or for an amount stipulated in the original contract. Such contracts are typically long-term and may extend to 40 or more years.

7- Build, Own, Operate (BOO): This type is considered to be a basic type of privatization where the private sector is granted the responsibility of building, operating, and managing the project besides complete ownership of all the project's assets. This type of contracts doesn't have a defined time frame and it is always applied on the brand new projects that have not started yet.

8- Sale: privatization can take several forms such as direct sale of an already existing public asset to a private domestic or foreign investor through bidding or auctions. A second form is selling the public asset's share to the public in order to enlarge the ownership of the public asset and this is usually applied in case of a financially stable public asset. A third form is leveraged buyout where the managers and/or the employees take over the ownership of the public asset (Zaki, 1999).

\subsection{How Does PPP Work?}

Bidding process: The public sector entity identifies the need for carrying out a specific project. Then, it starts making the appropriate advertisements in order to allow the interested private firms to apply for bidding upon which the public entity is to select the right private sector bidder who will then be granted a concession to implement the project.

Project Company: The private firm starts to raise funds from investors in order to be able to undertake the project. Usually a separate private company "The Project Company" is to be set up for undertaking the project so as to insulate the investors from risk of insolvency in case of project failure. This company is called (Special Purpose Vehicle SPV).

Sponsor: The Project Company's activities are to be managed by one or more private 
companies (the sponsor) to which the project company is considered to be direct/indirect subsidiary. These sponsors are the equity investment divisions of large private companies that want their facilities to deliver the project. This agreement is known as "Shareholders' agreement".

Documentation: The Project Company and the public entity are to write a contract "The Concession Agreement" specifying all the detailed terms and conditions of the project.

Contractors: Since the Project Company has no employees it has to sign two contracts. One of which will be signed with the Facilities Management Contractor who will be responsible for the delivery of facilities management services agreed upon in the concession agreement. The other is going to be with The Construction Contractor who is going to be responsible for the delivery of the construction works agreed upon in the concession agreement. Other needed functions might be subcontracted by other firms known as Subcontractors.

Funding: For financing the PPP, the Project Company will get private funds in the form of mixed investments, the smaller part of which from the sponsors and the rest from the lenders. The lenders will not be involved with the Project Company in the Financing Agreement but instead will sign with them The Security Agreement according to which the lenders are going to lend the funds to the Project Company in return for security over the project. There will often also be The Direct Agreement that will allow the lenders to "step in" to the Project Company's shoes in a situation where the project is going wrong and the Project Company is endangered by the public entity termination of the Concession Contract. Lenders might include commercial banks with experience in project financing, export credit agencies ("ECAs") that provide finance aiming at fostering national exports, multi-lateral agencies ("MLAs") which are governmental institutions owned by a number of governments promoting further economic development in developing countries than ECAs do, and development finance institutions ("DFIs") that provide long-term development finance for private sector enterprises in developing countries (European Commission, 2003).

\subsection{PPP Benefits and Risks}

An analysis of the viability of PPPs conducted by the World Bank showed that they have their benefits and their risks.

Well managed and structured PPPs can help achieve the following objectives:

1- Developing PPPs allows the government to benefit from the private sector technology and innovation in the provision of more efficient and operationally improved public services.

2- Motivating the private sector to deliver the projects within the agreed upon budget and time frame.

3- Using PPPs as a way of developing the local private sector capabilities through the involvement with large international organizations in joint ventures and/ or subcontracting opportunities for the local private firms in several infrastructure areas. This enhances a wider exposure of the local private firms and the government to foreign private participation and managing the PPPs in a way that ensures the effective transfer of skills resulting in 
modernized national firms capable of running their projects more efficiently and effectively.

4- Supporting the current public sector capabilities in order to be able to meet the increased demand for more developed infrastructure services.

5- Creating long term value for money through transferring risk partially to the private sector throughout the life of the project starting from its design, passing through its construction, its operations, and its maintenance (World Bank Report, 2015).

Potential risks that can be associated with public private partnerships:

1- The PPP projects' cycle cost might be greater than the traditional public sector procurement processes. Thus, the government must make sure that the costs involved are justified. There are several methods that have been developed by different PPP units around the world to analyze the costs and to look at the value for money.

2- Higher capital cost because of private borrowing as the additional cost of private finance is around $1 \%$ to $2 \%$. At the same time, the private firms are cautious about bearing risks that are out of their control and if they did, this would reflect on their prices. So, they have to be completely aware of the governmental actions towards any undertakings to increase tariffs, fairs...etc.

3- When there is a contract between two parties, there is a kind of insecurity emerges as a result of inappropriate cooperation that may lead to frustrated administrative efforts both sides. When a private firm enters into a tender procedure, it might not be guaranteed any kind of concession. These insecurities might limit the number of bidders which in turn reduce the competitiveness of the tender process.

4- Long term contracts might lead to inefficiencies as once the private party wins the tender, then it acts as a monopoly and because of lack of contestability and competition inefficiencies might emerge. Consequently, the terms of the contract must be clear and considering cases of any defaults, there should be payment arrangements to offset these defaults. While in case of continuous defaults, termination of contract might take place. On the other hand, the private firm should be awarded if the performance proved to be superior to the contractual standards.

5- Long term contracts result in stability and lower uncertainty but at the same time they create rigidity, and harness the ability to adapt to the changing conditions. So, flexibility must be allowed for scheme specific issues (Laan et al., 2001).

\section{Critical Success Factors of PPP Projects in Different Countries}

Suhaiza Isamil in her study in 2013 mentioned Jcobson and Choi's findings to assess the effective success factors in the PPP projects among ten criteria which included "specific plan/vision", "commitment", "open communication and trust", "willingness to compromise/collaborate", "respect", “community outreach", "political support", "expert advice and review", "risk awareness", and "clear roles and responsibilities" (Jcobson and Choi, 2008). The results revealed that "high degrees of commitment" and "shared vision between the client, architect, and contractor" are the most important factors for construction 
success. (Ismail, 2013).

- PPP in Australia:

Jefferies discussed in his study the CSFs of a stadium in Australia, which was built using the build operate own transfer (BOOT) mode of PPP. The author came up with 15 success factors that are relevant to the success of the project which were specific to: "compatibility/complementary skills among the key parties", "technical innovation in overcoming project complexity" and "efficient approval process" (Jefferies, 2006). Other important success factors that were found to be due to "environmental impact", "developed legal/economic framework", "political stability", "selecting the right project", "existing strategic alliances", "good resource management", "trust", "community support", "feasibility study", "transfer of technology", "financial capability", and "consortium structure". Jefferies analyzed in his study the CSF of the PPP are due to "negotiation", "client brief/outcome", "bid feature", "business diversification", "business viability", "competition”, "credit rating investor", "teamwork", "existing infrastructure", "delivery of asset", "investment growth", and "project identification". The most significant success factors for the Super Dome project are due to the fact that the government was managing the bidding process very well, the project agreement and the negotiation process were also very structured and details considered.

- PPP Projects in Lebanon:

As for the CSFs for the PPP projects in Lebanon, Jamali in 2004 investigated the CSF in the PPP in the telecommunication industry. The finding of his study revealed that "trust", "openness" and "fairness" are among the main factors of the project success. The CSFs for the thermal power were mainly due to the "level of project financing, management of the project company", "level of business operation, qualification of the contractor". While the CSFs of the wind power were due to the "competency of personnel of the project company", "financial capacity of the contractor", "expected profitability of the project", and the "legal environment" (Jamali, 2004).

- PPP in Malaysia:

Abdul Aziz and Kassim in 2011 conducted a similar study on PPP of housing projects and used the same 15 success factors that was identified by Abdul Aziz in 2010 in addition to investigating the objectives as well as the success and failure factors of PPP housing projects in Malaysia . In terms of the CSFs, the study revealed that "action against errant developers" is the most influential variable on the success of PPP housing, while "absence of robust and clear agreement" has the most impact on the failure of housing PPP's (Abdul Aziz and Kassim, 2011).

\section{Public Private Partnership in Egypt: Aspects, Goals, Impacts, and Insights}

Egypt is considered to be one of the MENA region leaders in the PPP field. PPPs are considered to be on the top of the Egyptian economic reform agenda so as to increase the private sector involvement in public services through leveraging private sector spending 
against public spending.

A cursory analysis of developing economies such as Egypt reveals that the infrastructural services (that have always been provided by the public sector) have been without evidence of substantial achievements, on the contrary an obvious deterioration has been noticeable over the past few years in specific. This indicates that the public sector doesn't have the adequate solutions for the emerging challenges facing a developing economy such as Egypt. This lacuna necessitates the emergence of alternative solutions for handling such inefficiencies and ineffectiveness of these services. One of the most viable alternatives is to depend (partially) on the private sector and this can be done through PPP which can lead to a better accomplishment of projects and delivery of services (especially the infrastructural services) that have been poorly provided by the public sector as a result of poor management or even because of imbalances that result from the increase in population in addition to budget deficits (http://www.pppcentralunit.mof.gov.eg). Dependence on long term PPP contracts can contribute to better construction and maintenance of infrastructure. The private sector participation provides a full range of designing, financing, construction, operating, management and maintenance of the facility during the contract period ranging from 15- 20 years, taking into account that financing and maintenance are obligatory for the private sector. According to these contracts, the Egyptian government is supposed to retain strategic control on the projects and follow up their implementation until they return to the government at the end of the contract period. These PPP long term contracts are governed by Law no. 67 for 2010 which establishes their legal framework (Akpan et al., 2013).

\subsection{Historical Background of the PPP in Egypt}

Kamel, Montaser \& Ab El Rashid in 2017 revealed in their study the historical background of the PPP in Egypt. Their study mentioned that during the first half of the twentieth century, cooperation started between the Egyptian government and the private sector, local and foreign till the issuance of the nationalization law during the reign of President Naser in the mid-century that absorbed these efforts and minimized the role of the private sector in favor of the public sector for two decades (Kamel et al., 2017).

In mid-seventies, Egypt was redirected from the socialist system of the sixties to the capitalism system through adopting the open door policies "Infetah" during the time of President Sadat. Despite the fact that the Egyptian economy achieved a remarkable growth till 1986, but Egypt experienced remarkable budget deficit of 14\% of the Gross Domestic Product, GDP (CBE, 1987) which increased to $17.2 \%$ by 1990 . The balance of payment deficit was running at a rate of 11.4 billion Egyptian Pounds, and the inflation rate was $15 \%$ (CBE, 1991). By mid-seventies,

The Egyptian Government started discussions with the International Monetary Fund (IMF) but actually the real actions were taken in 1991 when the government announced the Economic Reform and Structural Adjustment Program which was designed with guidance of IMF and the World Bank. The program's essential targets was to strengthen Egypt's economy (Korayem, 1997) and provide the necessary support and guidance to transform the Egyptian economy to a market-based economy rather than socialist economy (IMF, 1991). 
The Egyptian government enacted law 203 for year 1991 as a legislative frame of the privatization program which started seriously in the same year (EOG, 1991). The program targeted 314 public sector companies with assets of 104 billion EGP and 1.08 million employees (MOP, 1992).

Despite the government efforts towards the privatization program, it failed to introduce its program properly due to the loud opposing voices toward these programs that might end up releasing public employees for the benefit of the private companies and business people. That failure of accomplishing the privatization program from the part of government was a reason for its movement towards public private partnership which was the PPP (PCSU, 2002).

\subsection{PPP Projects in Egypt: Success and Failure Cases}

Askar and Gaballa in 2002 revealed in their study that the Egyptian government PPP program started in 1996 with the government plan to accomplish several projects in 1996 like the Tahrir Garage, Marsa Allam airport, EL Alamain International Airport, Power Plant in Sidi Krir, EL Fayum/Aswan High way and EL Khargah and Sharik EL Oinat High way project (Askar and Gaballa, 2002).

Kamel, Montaser \& Ab El Rashid in 2017 also mentioned in their paper that a feasibility study was conducted by the Aviation Authority with a fund from the Scientific Research Academy to evaluate Egypt's airports situation which revealed that there is a need for constructing new airports to serve the country's tourism, commercial and industrial aspects and the fact that the existing airports burdens the state budget.

Both Marsa Allam and Alamain airports were agreed to be constructed through PPP. The two projects were considered a success and failure cases despite that they were run under the same condition. Both were costal area airports, approved the same date and went through the same bidding condition and subjected to the bureaucracy and difficulties from the government authorities.

Marsa Alam airport achieved quiet a good profit while El Alamain airport had losses which caused their management to be questioned by the Control Authority. The bidders of Marsa Allam had different approach since they rented a helicopter on their expense to study the appropriate construction place for the airport and convinced the government with it and started operating with proper management and meeting projected milestones before its deadlines.

While EL Alamin bidders went through the same bidding requirements by the government without further investigations and precise study from their side, they faced the same obstacles from the government authority which resulted in lag in accomplishing the construction plan and severe accordingly severe losses. The government budget deficit caused the development plan of El-Alamain area to be always behind schedule. The airport income is too low even to cover the construction and running costs (Kamel et al, 2017).

\subsection{Establishment of PPP Central Unit}

The Egyptian government established the Public Private Central Unit (PPPCU) in 2006 under 


\section{Ml Macrothink}

International Journal of Human Resource Studies

ISSN 2162-3058 2018, Vol. 8, No. 3

the umbrella of the Ministry of Finance. Accordingly, in 2006 the Government of Egypt has developed the Public Private Partnership Central Unit (PPPCU) at the Ministry of Finance to coordinate the PPP project stages across the concerned ministries or public authorities (Hannoura, 2013).

The Public Private Partnership Central Unit is considered to be "Center of Expertise" which has been entitled to carry on the mission of introducing, communicating, overseeing, and implementing the PPP policy. The very basic duty for the unit is ensuring that the PPP proposals are appropriately analyzed upon the needs and value, receiving the required budget approvals, and the selection of the private partner made according to a fair bidding process.

The main responsibilities of this unit is to set a PPP policy among the state ministries or authorities, responsible for managing the early stages of the PPP, help the concerned public bodies with technical advisory support and attend tender committees' performance to ensure fairness and no fraud actions are taken to be in compliance with legislative framework.

The Central Unit roles are as Follows:

- Report to supreme Committee for projects approval and recognize issues that may impede the PPP program.

- Standardization of Contracts.

- Provision of technical monitoring techniques for implementation.

- Examine projects Ability to PPP Structure

- $\quad$ Technical \& legal due diligence

- Robustness of Bidding document

- Financial Modelling

- Prepare Draft Direct Agreements

- Setting Ministry of Finance Guarantees

- Studying Funding Market Intelligence

- Financial Risk Mitigation

- Risk Allocation Studies

- Assistance in Securing Properly Priced Funding

- Enhancement off Funding Market tools

- Set PPP guidelines and methodologies appropriate to Egypt

- Acting as a Central Complaints Resolution Office for PPP investors (http://www.pppcentralunit.mof.gov.eg) 


\subsection{Recorded Improvement in PPP Performance}

After the establishment of the PPPCU, it was obvious that many of the past problems were resolved and the PPP impediments were under control from the stage of announcing the winning bidder to the stage of signing the contract. In 2007 the New Urban Communities Authority (NUCA) under the umbrella of PPPCU supervision invited bidders in the New Cairo area in the fields of building, operation, and maintenance of New Cairo Wastewater Treatment Plant. The contract was done under PPP delivery for 20 years but the ownership will be transferred back to NUCA. No significant impediments appeared through different bidding stages till the step of announcing the winning bidder till the step of signing the contract. (MOF, 2016).

The parliament law 67 in 2010 to regulate the PPP was acted upon by 2011 to cover all the tiny details of the project stages that paved the way for a very encouraging environment for the PPP in Egypt (EOG, 2011). Later, after the January $25^{\text {th }}$ revolution, the political instability taking place in the country delayed the projects activities which pushed away lot of investors.

\section{Discussion and Analysis}

According to all that we have discussed earlier, there is a wide spread consensus that exclusive dependence on the government is not viable; on the other hand, complete reliance on private sector will not produce desired and optimal outcomes. As a result, there is an urgent dependence on PPPs which are considered to be key to the government's economic reform agenda and strategy to increase private sector involvement in public services through leveraging private spending against public spending. PPPs bring together consortia including developers, investors, constructors and other service providers to finance, construct, operate and maintain assets through long term contracts for the development of high quality infrastructure.

It is clear that the PPP witnessed success and failure case in Egypt throughout its history. Despite the issuance and regulations of the PPP through issuing law 67 that was acted on in 2011 to regulate the projects environment under PPP, however, the political stability and economic instability after the January revolution has a negative impact on PPP. Egypt has been facing the challenge of moving its gear again in all sectors after the impact of the January revolution, so, there is a crucial need from the part of the government in the coming period to strengthen the public private partnership.

The most important in all these projects for the government of Egypt are the lessons learnt from the success and failure projects to be able to sustain its success with the PPP projects. The success cases in the previous PPP like Marsa Allam airport should be maximized through replicating the success factor and spreading the awareness with it among public and private entities and also counteracting the failure factors in previous projects like EL Allamain airport project.

It should be considered that the success of the PPP in Egypt will depend to some extent on the environmental factors having to do with political and economic stability and the legal framework. 


\section{Mll Macrothink}

International Journal of Human Resource Studies

ISSN 2162-3058

2018, Vol. 8, No. 3

There is a strong need to develop a shared vision between both the public and private entities which can be built using good governance, proper management and accurate feasibility study, transparency, commitment, trust, loyalty, fairness, team work, proper negotiation, attention to details and milestone follow ups during the durations of the different projects. The concept of win-win relation should always be the intention of both parties.

\section{Conclusion}

This paper discusses the public private partnership in Egypt with objective of analyzing the role of both parties in fostering real cooperation that enables efficient and quality public goods and services. The paper comprises four sections. In the first section, it discusses the concept of PPP, how does it work, its methods, benefits and risks. In the second section, it discusses, the critical success factors of PPP in different countries like Australia, Lebanon, Malaysia. Then in third and fourth section, it discusses the case of Egypt with its PPP aspects goals, impact, and insights, PPP historical background, success and failure cases of its PPP. The study recommends a real need for public private cooperation in the coming period for the developmental goals taking place in Egypt in the presence of political and economic stability and considering the critical success factors in PPP with regards to good governance, proper management, transparency, commitment, loyalty, trust and a win-win relation.

\section{References}

Abdul, A. A. R., \& Kassim, P. S. J. (2011). Objectives, Success and Failure Factors of Public-Private Partnerships in Malaysia. Habitat International, 35, 150-7. https://doi.org/10.1016/j.habitatint.2010.06.005

Akpan, P., Racheal, A., Uzoma, O., \& Genevive, O. (2012). Public Private Partnership in Emerging Economy Evidence from Infrastructural and Manufacturing Subsectors of Nigeria, International Journal of Sustainable Development, 5. [Online] Available: http://www.ssrn.com/link/OIDA-Intl-Journal-Sustainable-Dev.html.

Askar, M., \& Gab, A. A. (2002). Problems Facing Parties in Build Operate Transfer Projects in Egypt. Journal of Management in Engineering, 18(4), 173-178. https://doi.org/10.1061/(ASCE)0742-597X(2002)18:4(173)

Barlow, J., Roehrich, J. K., \& Wright, S. (2013). Europe Sees Mixed Results From Public-Private Partnerships For Building And Managing Health Care Facilities And Services. Health Affairs, 32(1), 146-154. [Online] Available: http://www.ncbi.nlm.nih.gov/pubmed/23297282.

Central Bank of Egypt. (CBE). Annual Reports for the Years, 1987/88, 1990/91, 1991/92. Egypt Official Gazette (EOG); Vol., May 2010 \& January 2011.

El Dessouky, I. (1995). Privatization and Economic Reform in the Developing Countries; Dar El Nahda El Arabiya- Cairo.

El Sadek, A. (1995). The Efforts and the Hurdles of Privatization in the Arab Countries; Economic Studies Institute- Abou Dhabi. 
European Commission: Directorate Central Regional Policy; Guidelines for Public Private Partnership, European Commission, March 2003; [online] Available: http://europa.eu.int/comm/regional_policy/sources/docgener/guides/PPPguide.html.

Hannoura, A. (2013). Ministry of Finance- PPP Central Unit- Cairo; [Online] Available: http://www.mcit.gov.eg/Upcont/Documents/20134151031MoF-\%2011\%20Apr\%202013.pdf

International Monetary Fund (IMF). Memorandum on Economic Policy of the Egyptian Government, April 191991.

Ismail, S. (2013). Critical Success actors of public Private Partnership (PPP) Implementation in Malaysia. Asia-Pacific Journal of Business Administration, 5(1), 6-19. https://doi.org/10.1108/17574321311304503

Jacobson, C., \& Choi, S. O. (2008). Success Factors: Public Works and Public-Private Partnerships. International Journal of Public Sector Management, 21(6), 637-57. https://doi.org/10.1108/09513550810896514

Jamali, D. (2004). Success and Failures Mechanisms of Public Private Partnerships (PPPs) in Developing Countries. The International Journal of Public Sector Management, 17(5), 414-30. https://doi.org/10.1108/09513550410546598

Jefferies, M. (2006). Critical Success Factors of Public Private Sector Partnerships: a Case Study of the Sydney Super Dome, Engineering, Construction and Architectural Management, 13(5), 451-62. https://doi.org/10.1108/09699980610690738

Kamel, M., Montaser, A., \& Abd, EL-Rachid, I., (2017). Public Private Partnership in Egypt CSE, Annual Conference Leadership in Sustainable Infrastructure Vancouver, May 31 - June 3 .

Korayem, K. (1997). Egypt's Economic Reform and Structural Adjustment, The Egyptian Centre for Economic Studies, Working Paper, 19, October 1997.

Laan, Van de G., Ruys, P., \& Talman, D. (2001). Optimal Provision of Infrastructure using Public Private Partnership Contracts; Tinbergen Institute; Discussion Paper.

Ministry of Finance (MOF). (2016). The Financial Statement of the Fiscal Year 2015/2016. Egypt.

Ministry of Planning (MOP). (1992). The Third Five-Year Plan for Economic and Social Development (1992/93 - 1996/97), Egypt.

Privatization Coordination Support Unit (PCSU). Privatization in Egypt: Quarterly Review, April-June, 2002, CARANA Corporation, Cairo, Egypt.

World Bank Report; Government Objectives: Benefits and Risks of PPPs, October 2015; [Online] Available: www.worldbank.org/pppirc

World Development Report (1994). Infrastructure for Development; [Online] Available: https://openknowledge.worldbank.org/handle/10986/5977 


\section{Macrothink}

International Journal of Human Resource Studies

ISSN 2162-3058 2018, Vol. 8, No. 3

Zaki, M. S. (1999). Build Operate Transfer system (BOT), The International Consultative Research Center - Cairo.

\section{Copyright Disclaimer}

Copyright for this article is retained by the author(s), with first publication rights granted to the journal.

This is an open-access article distributed under the terms and conditions of the Creative Commons Attribution license (http://creativecommons.org/licenses/by/4.0/). 